\title{
メカニズムコントロールが鉄筋コンクリートフレーム構造の 損傷過程と崩壊確率に及ぼす影響 \\ INFLUENCES OF MECHANISM CONTROL FOR REINFORCED CONCRETE FRAME STRUCTURES ON PROCESSES OF DAMAGE AND PROBABILITIES OF COLLAPSE
}

\author{
長 江 拓 也*，林 静雄**，ルイス イバラ***，へルムットクラウィンクラー**** \\ Takuya NAGAE, Shizuo HAYASHI, Luis F. IBARRA \\ and Helmut KRAWINKLER
}

\begin{abstract}
The quantitative representation of the performance of building is not straightforward. At present, the mechanism formed by strong columns and weak beams (i.e. complete mechanism) is strongly recommended as a design concept for multistory frame structures. However, from the viewpoint of reparability, it is generally difficult to repair all hinges in the beams in the case of complete mechanism. In addition, costs of downtime can be high because all of stories of the building become targets of repairing. Thus, this research comes up with a concept of mechanism control that intends to concentrate damages to the lower part of the frame structure and keep the rest of the structure (the higher part) intact. The type of mechanism can be controlled by appropriately reinforcing the members in the upper part. However it is obvious that the extreme case, i.e. soft-first-story building can produce poor collapse capacity. Thus, for this design, it becomes very important to show the balance between the reparability and the safety against collapse. In this report, damage processes including collapse are presented from the results of incremental dynamic analyses, which were conducted for reinforced concrete frame structures with different size of partial mechanisms. The response assessment for the structures was performed through probabilistic approaches, and eventually the probability of collapse was computed and compared.
\end{abstract}

\section{Keywords: reinforced concrete building, frame structure, partial mechanism, incremental dynamic analysis, process of damage, probability of collapse 鉄筋コンクリート造建物, フレーム構造, 部分崩壊メカニズム, 漸增動的地震応答解析, 損傷過程, 崩壊確率}

1. はじめに

現在，フレーム構造に対する耐震設計においては, Fig.1(a)に示す

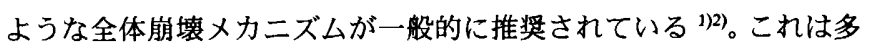
数の梁ヒンジがエネルギ一吸収機構として働き, 建物全体のエネル ギー吸収能力を高めるという考えに基づいている。しかしながら, 建物の崩壊をとってみても, すべての梁の降伏を保証することによ って, 結果的にどれほどその安全性が向上するかを定量的に示すこ とは簡単でない。

一方，地震後の修復性といった観点から考えれば，すべての梁端 ヒンジを降伏させることは, 必ずしも効率がいいとは言えない。建 物の全層が補修対象となるので, 住宅, 会社事務所を問わず, 全建 物使用者の一時的な立ち退きを余儀なくされることとなり，ダウン タイムから生じるコスト負担は大きくなる。

地震時のメカニズム形式は, 設計時における部材強度設定により,
特別な工法やデバイスなどは用いずとも，比較的容易にコントロー ルできると考えられ, Fig.1(b)に示すように, 大地震時における建物

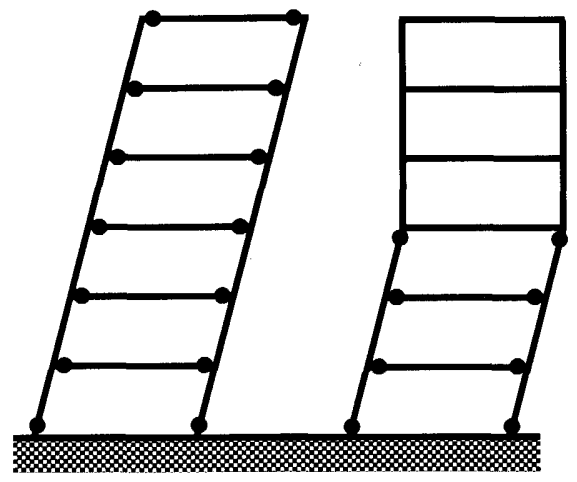

(a)

Fig. 1 (a) Complete mechanism and (b) Partial mechanism

$*$ 京都大学防災研究所 $\mathrm{COE}$ 研究員 $\cdot$ 博士 $($ 工学)

** 東京工業大学建築物理研究センター 教授・工博

****サウスウエスト研究所 Ph. D

**** スタンフォード大学 教授・Ph. D.
COE Research Fellow, Disaster Prevention Research Institute, Kyoto University, Dr. Eng.

Prof., Structural Engineering Research Center, Tokyo Institute of Technology, Dr. Eng.

Senior Research Engineer, Southwest Research Institute, Ph. D.

Prof., Dept. of Civil and Environmental Engineering, Stanford University, Ph. D. 
のメカニズムをある領域内にとどめれば，残りの部分は無損傷に抑 えることができる。これにより, 補修工事の効率化, ダウンタイム コストの減少が期待できる。また, 鉄筋コンクリート造建物では, 全体崩壊メカニズムを目指すために，スリットによって袖壁・腰壁 などの雑壁と, 梁・柱からなるフレームを分離することが一般的に 行われる。しかし，こうしたスリットも無損傷計画部分においては 設ける必要がなくなる。むしろ，今まで捨て去っていた雑壁等から

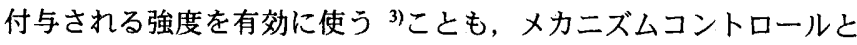
いう観点からは重要となってくる。

ただし,この場合, 地震時にエネルギーを吸収する部材の数が減 少することは否めない。したがって, 損倠過程から崩壊に対する安 全性までの耐震性能を明示することが，より重要な鍵となる。

地震時における建物の性能を，工学的にどのような形で表現する のかを特定するのは大きな課題であるが, PEER ${ }^{4)}$ (Pacific Earthquake Engineering Research Center）においては，施主に対する明快な性能 表現を目指し，地震八ザードに基づく確率論的なアプローチ 5)を採 用している。この中で, 地震により建物に生じる応答工学量を評価 するための手法として, 渐增動的地震応答解析が挙げられる ${ }^{67}$ 》あ る地震強さで基準化された数十個一組の地震動群に対して, 非線形 時刻歴応答解析を行い，この地震強さを渐增させることにより，建 物の地震応答を統計的かつ連続的に把握することができる。

本報告では，メカニズム領域の異なる鉄筋コンクリートフレーム 構造に対して，40 個一組の地震動群を用い，渐增動的地震応答解析 を行う。その結果から得られる応答工学量を整理することで，損傷 過程を比較検討するとともに，最終的には崩䆏に対する安全性を崩 壊確率として表現する。
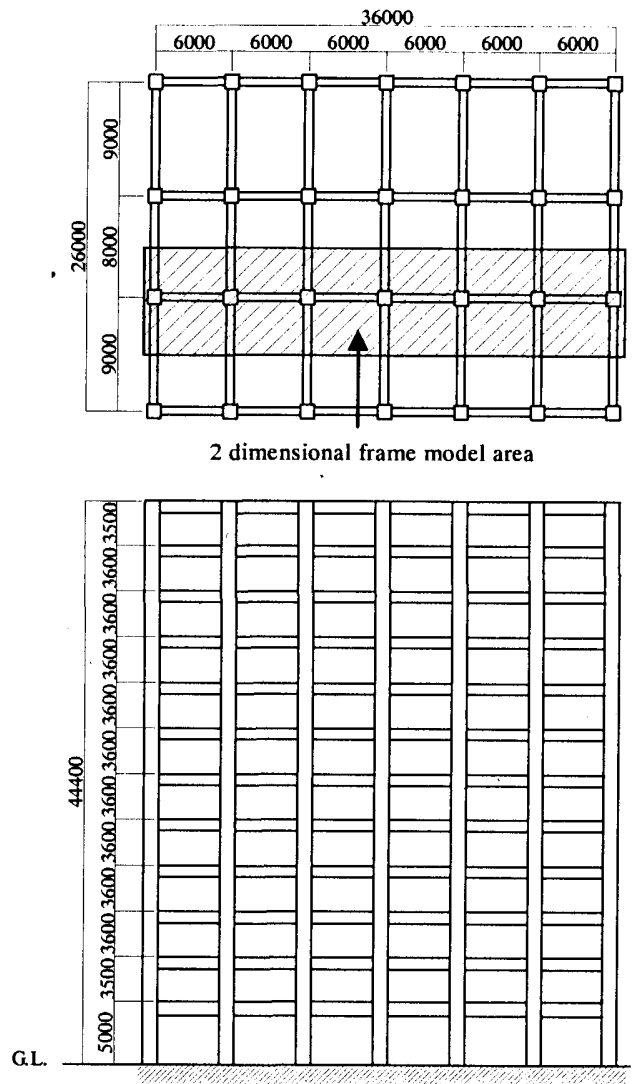

Fig.2 The building analyzed in this study
2. 性能評価アプローチ

2.1 解析モデル

本研究では, 一連のモデル化を確定論的に行う。（ただし，漸増動 的地震応答解析の結果に対する影響は，建物のモデル化における，

質量, 減衰, 剛性, 強度などの変動より, 基準化される地震動の変 動の方が，はるかに大きい8)。

基本となる建物は，終局強度型設計指針 ${ }^{1)}$ の設計例 2 に示される 事務所建物を参考とした 12 階建て鉄筋コンクリート造建物で,一構 面を取り出し，基礎固定の 2 次元フレームとしてモデル化する。こ の建物は，設計指針の設計手順において全体崩壊メカニズムに対す る機椪設計と保証設計が行われている。すなわち，Fig.3 に示す首 せん断力倸数 $C \mathrm{i}$ に基づく水平荷重と鈶直荷重の組み合わせに対す る部材応力を上回るように梁ヒンジの降伏強度が設計され（機構設
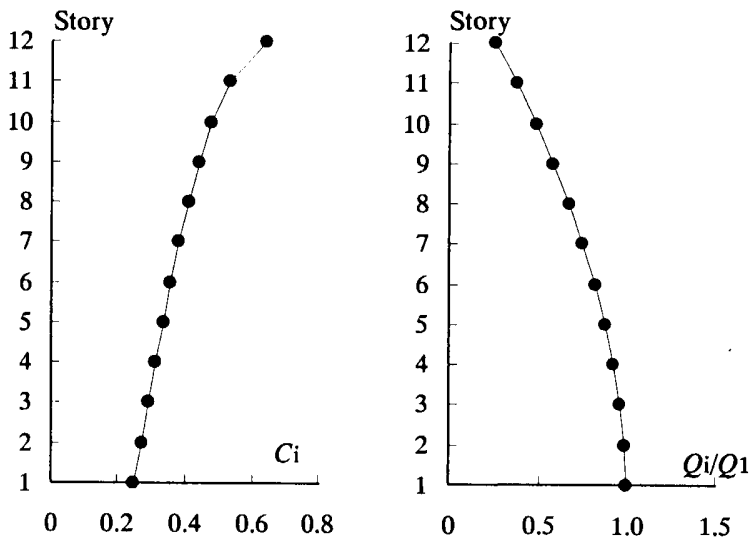

$C_{\mathrm{i}}=Q_{\mathrm{i}} / W_{\mathrm{i}} \quad Q_{\mathrm{i}}$ : shear force of each story $W_{\mathrm{i}}$ : weight of a portion above the story $Q_{1}$ : shear force of the first story

Fig.3 Horizontal-force condition for the original design

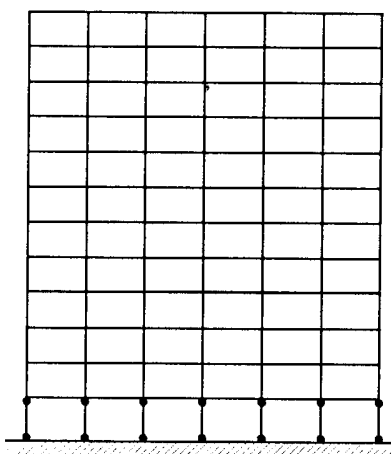

Case-1

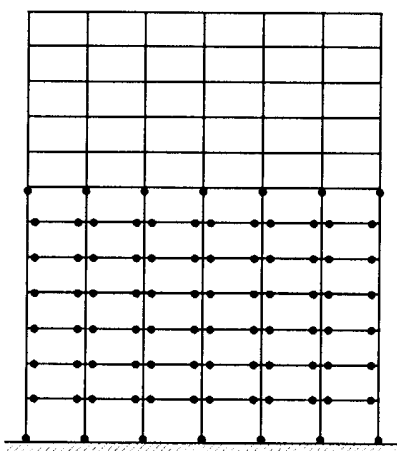

Case-3

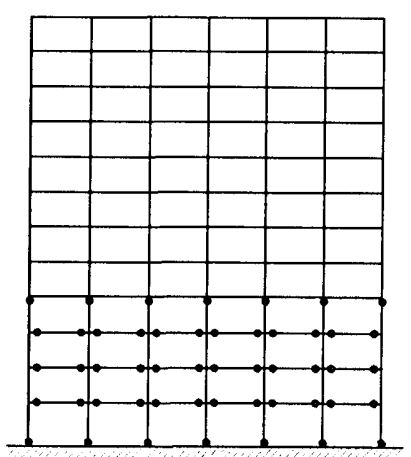

Case-2

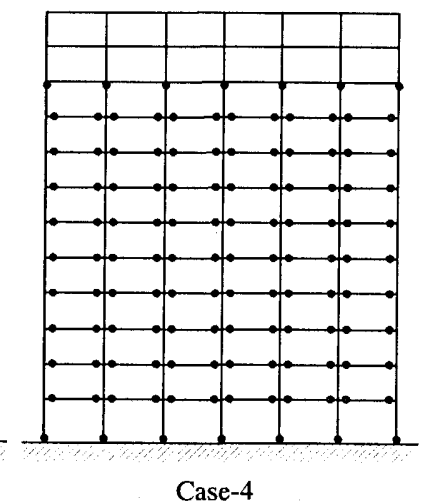

Case-4
Fig.4 Partial mechanisms assumed in this study 
計),さらにその梁降伏を保証するように柱の降伏強度が設計されて いる (保証設計)。結果的に, 梁の降伏強度の分布形状は, Fig.3に 示す設計用層せん断力の分布形状 $Q \mathrm{i} / Q_{1}$ にほぼ一致する。

これに対し，上層部が十分に補強された場合を仮定して，4 種類 の部分崩壊メカニズムを定義する (Fig.4)。検討の対象とするのは, メカニズム領域が 1 階のみの場合, 1 階から 4 階までの場合, 1 階か ら 7 階までの場合, および 1 階から 10 階までの場合で, メカニズム 領域を 3 層ずつ增大させている。

メカニズム領域内, 梁および 1 階柱脚は, 上記の設計から与えら れる主筋量に基づき，非線形部材としてモデル化する。今回新たに ヒンジを計画することとなるメカニズム領域内最上階の柱頭に関し ては, 引張主筋比 P $\mathrm{t}$ にして $0.4 \%$ を限值とし, 上記の設計用曲げ モーメントに曲げ降伏強度ができるだけ近くなるよう主筋量を減ら したうえで, 非線形部材としてモデル化する。(結果として, Case-2 における 4 階の柱の場合に, 30\%程度設計用曲げモーメントをオー バーするが，他の場合はそれ以下に収まっている。）

無損傷計画部分の部材およびメカニズム領域内でヒンジを計画し ない柱は, 弾性部材としてモデル化する。

非線形部材における材端回転ばねの初期剛性 $K_{1}$ は, コンクリート のヤング係数 $E_{\mathrm{c}}$ に基づき, 式(1)より求める。

$$
K_{1}=\frac{6 E_{\mathrm{c}} \cdot I}{l}
$$

ここにＩは断面二次モーメント，lは内法スパン長さ。

材端回転ばねの曲げモーメント $M$ と回転角 $\theta$ の関係における非線 形履歴特性としては, 武田モデル ${ }^{9)}$ を Fig.5 に示すようにテトラリニ アの骨格曲線とし，最大耐力後の負勾配を考慮する。繰り返しによ る耐力劣化は考慮しない。

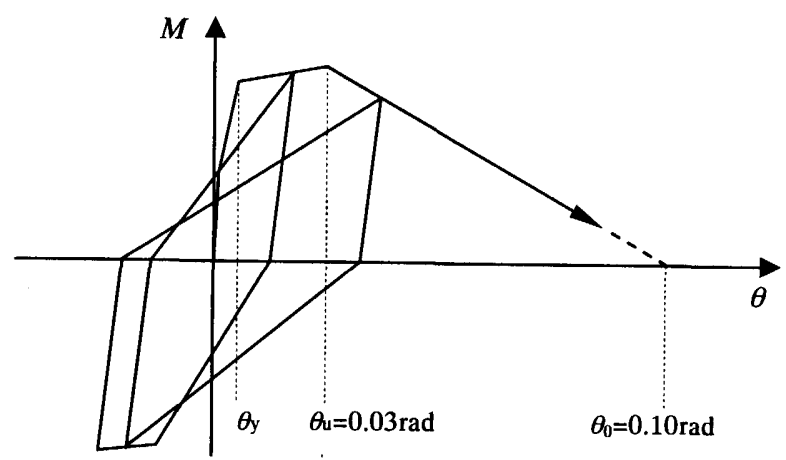

Fig.5 Assumed hysteretic characteristics of rotational springs at the ends of inelastic members

曲げひび割れ強度および曲げ降伏強度を曲げ解析から求め, 曲げ 降伏時回転角 $\theta_{y}$ を菅野式 ${ }^{10)}$ より求める。曲げ降伏後剛性は, 初期剛

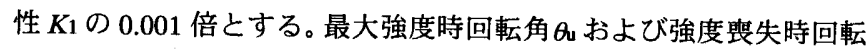
角 $\theta_{0}$ は勒性設計された部材を仮定し, すべての部材を一律にそれぞ れ 0.03 rad および 0.10rad とする。

大変形時に問題となる $P-D$ 効果に関しては, 幾何剛性マトリック スを用いて部材レベルで評価する。

内部減衰は瞬間剛性比例型とし, 減衰定数 $h$ を弾性一次固有周期 $T_{1}$ に対して $5 \%$ とする。建物の弾性一次固有周期 $T_{1}$ はすべてのケー スにおいて等しく, 固有値解析の結果において $T_{1}$ は 0.813 秒である。 Fig.6には, Fig.3の層せん断力倸数 $C_{\mathrm{i}}$ 分布に基づく非線形プッシ

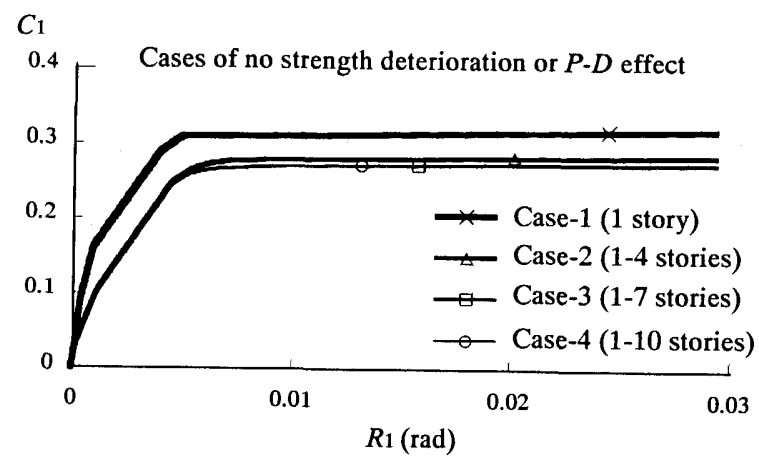

Fig.6 Relations between shear force ratio and inter story drift ratio of the first story, which is from static pushover analyses

ユオーバー解析の結果から, 1 階層せん断力係数 C 1 と 1 階層間変形 角 $R_{1}$ の関係を示す。ただし, 非線形部材の耐力低下と $P$ - $D$ 効果は, 非線形プッシュオーバー解析には組み込まれていない。図より，メ カニズム領域が 1 階から 4 階までの Case-2, 1 階から 7 階までの Case-3, および 1 階から 10 階までの Case-4 は, ほぼ同一線上にあ ることがわかる。これは, メカニズム領域内の部材が機構設計で設 定された応力レベルに達することで, それぞれ保有水平耐力に達し たことを意味している。図中, 1 階が層崩壊する Case-1 は, 前述の ように柱の主筋量を減らしているが, その性状が柱のみに支配され るため, 保有水平耐力が他のものより $15 \%$ 程度高い值となっている。 柱の曲げ強度は軸力に大きく影響されるため, このような結果とな るが, 本研究では, 現実的な建物の条件に基づくという観点から, 保有水平耐力が他のものとできるだけ近くなるようにして, 比較の 対象とする。

2.2 地震動とサイトのハザード

本研究では, 米国カリフォルニア州における硬めの地盤（NEHRP において地盤夕イプ ${ }^{11)}, 183 \mathrm{~m} / \mathrm{sec}<V_{\mathrm{s}}<366 \mathrm{~m} / \mathrm{sec}$ または $15<\mathrm{N}<50$, $V_{\mathrm{s}}$ : せん断波速度, $\mathrm{N}$ ：標準貫入試験による $\mathrm{N}$ 值）で記録された 40 個の地震動群 ${ }^{12)}$ を漸增動的地震応答解析に用いる。これらの地震動 のモーメントマグニチュード $M_{\mathrm{w}}$ は 6.5 から 6.9, サイト震源間距離 $R$ は $13 \mathrm{~km}$ から $40 \mathrm{~km}$ である。Table 1 に地震動の詳細を示す。

地震動を基準化するためのスカラーである地震強さは, 建物の一 次固有周期 $T_{1}$ を持つ弾性一質点系の最大加速度応答値 $S_{\mathrm{a}}\left(T_{1}\right)$ とする。 このときの減衰定数 $h$ は, $5 \%$ として定義される。サイトの地震に対 するハザード解析 ${ }^{13)}$ の結果から， $S_{\mathrm{a}}\left(T_{1}\right)$ のハザードカーブを得るこ

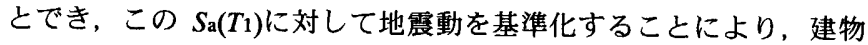
の地震応答を効率よく（ばらつきを抑えて）評価できる ${ }^{14)}$ 。

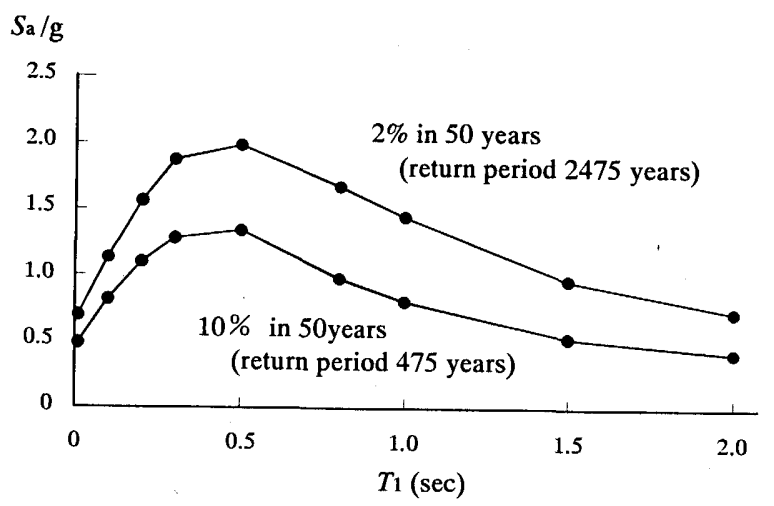

Fig.7 Uniform hazard spectra at Van Nuys 
Table 1 Detailed characteristics of the ground motions used in this study

\begin{tabular}{|c|c|c|c|c|c|c|c|c|c|c|}
\hline No. & Record ID & Event & Year & Mw & Station & $\mathrm{R}(\mathrm{km})$ & NEHRP Site ${ }^{*}$ & PGA(g) & $\mathrm{PGV}(\mathrm{cm} / \mathrm{s})$ & PGD $(\mathrm{cm})$ \\
\hline 1 & IV79cal & Imperial Vallcy & 1979 & 6.5 & Calipatria Fire Station & 23.8 & D & 0.078 & 13.3 & 6.2 \\
\hline 2 & IV79chi & Imperial Vallcy & 1979 & 6.5 & Chihuahua & 28.7 & D & 0.270 & 24.9 & 9.1 \\
\hline 3 & IV79cmp & Imperial Vallcy & 1979 & 6.5 & Compuertas & 32.6 & $\mathrm{D}$ & 0.186 & 13.9 & 2.9 \\
\hline 4 & IV79e01 & Imperial Vallcy & 1979 & 6.5 & El Centro Array \#1 & 15.5 & $\mathrm{D}$ & 0.139 & 16 & 10.0 \\
\hline 5 & IV79e12 & Imperial Vallcy & 1979 & 6.5 & El Centro Array \#12 & 18.2 & $\mathrm{D}$ & 0.116 & 21.8 & 12.1 \\
\hline 6 & IV79e13 & Imperial Vallcy & 1979 & 6.5 & El Centro Array \#13 & 21.9 & $\mathrm{D}$ & 0.139 & 13 & 5.8 \\
\hline 7 & IV79nil & Imperial Vallcy & 1979 & 6.5 & Niland Fire Station & 35.9 & D & 0.109 & 11.9 & 6.9 \\
\hline 8 & IV79pls & Imperial Vallcy & 1979 & 6.5 & Plaster City & 31.7 & D & 0.057 & 5.4 & 1.9 \\
\hline 10 & IV79wsm & Imperial Vallcy & 1979 & 6.5 & Westmorland Fire Station & 15.1 & $\mathrm{D}$ & 0.110 & 21.9 & 10.0 \\
\hline 11 & LP89agw & Loma Prieta & 1989 & 6.9 & Agnews State Hospital & 28.2 & $\mathrm{D}$ & 0.172 & 26 & 12.6 \\
\hline 12 & LP89cap & Loma Prieta & 1989 & 6.9 & Capitola & 14.5 & $\mathrm{D}$ & 0.443 & 29.3 & 5.5 \\
\hline 13 & LP89g03 & Loma Prieta & 1989 & 6.9 & Gilroy Array \#3 & 14.4 & $\mathrm{D}$ & 0.367 & 44.7 & 19.3 \\
\hline 14 & LP89g04 & Loma Prieta & 1989 & 6.9 & Gilroy Array\#4 & 16.1 & D & 0.212 & 37.9 & 10.1 \\
\hline 15 & LP89gmr & Loma Prieta & 1989 & 6.9 & Gilroy Array $\# 7$ & 24.2 & $\mathrm{D}$ & 0.226 & 16.4 & 2.5 \\
\hline 16 & LP89hch & Loma Prieta & 1989 & 6.9 & Hllister City Hall & 28.2 & $\mathrm{D}$ & 0.247 & 38.5 & 17.8 \\
\hline 17 & LP89hda & Loma Prieta & 1989 & 6.9 & Hllister Differential Array & 25.8 & $\mathrm{D}$ & 0.279 & 35.6 & 13.1 \\
\hline 18 & LP89hvr & Loma Prieta & 1989 & 6.9 & Halls Valley & 31.6 & $\mathrm{D}$ & 0.134 & 15.4 & 3.3 \\
\hline 20 & LP89slc & Loma Prieta & 1989 & 6.9 & Palo Alto-SLAC Lab. & 36.3 & $\mathrm{D}$ & 0.194 & 37.5 & 10.0 \\
\hline 21 & LP89svl & Loma Prieta & 1989 & 6.9 & Sunnyval-Colton Ave. & 28.8 & D & 0.207 & 37.3 & 19.1 \\
\hline 22 & NR94cen & Northridge & 1994 & 6.7 & LA-Centinela St. & 30.9 & $\mathrm{D}$ & 0.322 & 22.9 & 5.5 \\
\hline 23 & NR94cnp & Northridge & 1994 & 6.7 & Canoga Park-Topanga Can. & 15,8 & $\mathrm{D}$ & 0,420 & 60.8 & 20.2 \\
\hline 24 & NR94far & Northridge & 1994 & 6.7 & LA-N Faring Rd. & 23.9 & D & 0.273 & 15.8 & 3.3 \\
\hline 25 & NR94fle & Northridge & 1994 & 6.7 & LA-Fletcher Dr. & 29.5 & D & 0.240 & 26.2 & 3.6 \\
\hline 26 & NR94glp & Northridge & 1994 & 6.7 & Glendale-Las Palmas & 25.4 & D & 0.206 & 7.4 & 1.8 \\
\hline 27 & NR94hol & Northridge & 1994 & 6.7 & LA-Hollywood Stor FF & 25.5 & D & 0.231 & 18.3 & 4.8 \\
\hline 28 & NR94lh1 & Northridge & 1994 & 6.7 & Lake Hughes\#1\# & 36.3 & D & 0.087 & 9.4 & 3.7 \\
\hline 29 & NR941v2 & Northridge & 1994 & 6.7 & Lake Hughes\#2\# & 37.7 & $\mathrm{D}$ & 0.063 & 7.2 & 1.6 \\
\hline 30 & NR94lv6 & Northridge & 1994 & 6.7 & Lake Hughes\#6\# & 38.5 & $\mathrm{D}$ & 0.178 & 14.4 & 2.1 \\
\hline 31 & NR94nya & Northridge & 1994 & 6.7 & LA Crescenta-New York & 22.3 & D & 0.159 & 11.3 & 3.0 \\
\hline 32 & NR94pic & Northridge & 1994 & 6.7 & LA-Pico\&Sentous & 32.7 & $\mathrm{D}$ & 0.186 & 14.3 & 2.4 \\
\hline 33 & NR94stc & Northridge & 1994 & 6.7 & Northrige-17645 Saticoy St. & 13.3 & D & 0.368 & 28.9 & 8.4 \\
\hline 34 & NR94stn & Northridge & 1994 & 6.7 & LA-Saturn St. & 30.0 & D & 0.474 & 34.6 & 6.6 \\
\hline 35 & NR94ver & Northridge & 1994 & 6.7 & LA-E Vernon Ave & 39.3 & D & 0.153 & 10.1 & 1.8 \\
\hline 36 & SF71pel & San Fernando & 1971 & 6.6 & LA-Hollywood Stor Lot & 21.2 & D & 0.174 & 14.9 & 6.3 \\
\hline 37 & SIn87bra & Superstition Hills & 1987 & 6.7 & Brawley & 18.2 & D & 0.156 & 13.9 & 5.4 \\
\hline
\end{tabular}

$M$ w: Moment magnitude, $R$ : Source to site distance, PGA, PGV, and PGD: Peak ground acceleration, peak ground velocity, and peak ground displacement *Definition of Type D in NEHRP ${ }^{7)}: 183 \mathrm{~m} / \mathrm{sec}<V_{\mathrm{s}}<366 \mathrm{~m} / \mathrm{sec}$ or $15<N<50$, where $V_{\mathrm{s}}$ is shear velocity and $N$ is $\mathrm{N}$ value from the standard penetration test

$S \mathbf{a} / \mathbf{g}$

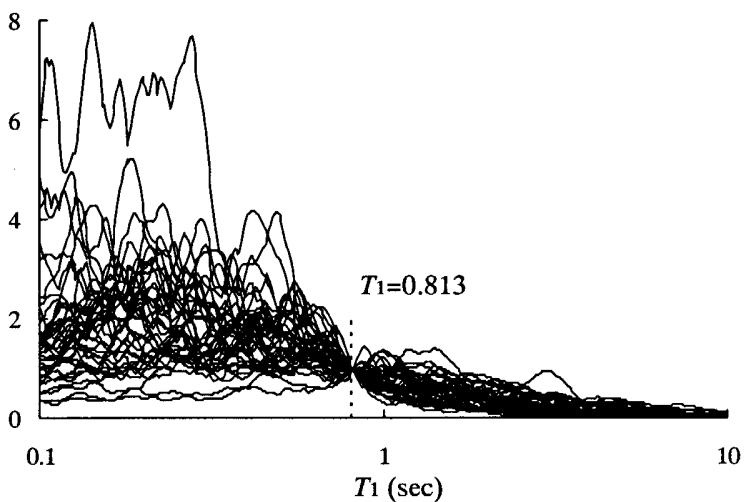

Fig.8 Acceleration spectra of ground motions scaled by the intensity measure $\mathrm{Sa}\left(T_{1}\right)$ of $10 \%$ probability in 50 years

NEHRP において地盤タイプ D に分類される米国カリフォルニア 州 Van Nuys に対して行われた地震ハザード解析の結果として, 一様 ハザードスペクトル ${ }^{15)}$ を Fig.7 に示し, 地震ハザードの資料として 用いることとする。この一様ハザードスペクトルは，代表的な一次 固有周期 $T_{1}$ に対して, 同じ発生確率の $S_{\mathrm{a}}\left(T_{1}\right)$ を結んだものである。

解析に用いる地震動は, 解析対象の建物の $T_{1}=0.813$ 秒に対する $S_{\mathrm{a}}\left(T_{1}\right)$ が等しくなるように, その加速度データがスケールされ, $S_{\mathrm{a}}\left(T_{1}\right)$
のレベルに応じて発生確率が定義される。Fig.8には, 地震強さ $S_{\mathrm{a}}\left(T_{1}\right)$ を 50 年発生確率 $10 \%$ のザードレベルに基準化した場合の加速度 応答スペクトルを示すが, $T_{1}=0.813$ 秒の $S_{\mathrm{a}}\left(T_{1}\right)$ を通り, そこから離 れることにより, バラツキが生じることとなる。

\section{3 漸増動的地震応答解析と崩壊キャパシティ}

Fig.9 に漸増動的地震応答解析と崩壊キャパシティの概念を示す。 縌軸に地震強さである $S_{\mathrm{a}}\left(T_{1}\right)$ （以降， $\left.S_{\mathrm{a}}\right)$ をとり，左横軸には地震 動の年間超過度数 $\lambda \mathrm{sa}$ を, 右横軸には応答工学量として最大層間変形 角 IDR max をとつている。Fig.9 の右側を見ると $S_{\mathrm{a}}$ が上がるにつれ， $I D R_{\max }$ が增えていく傾向にある。一方，途中， $S_{\mathrm{a}}$ が上がるにもかか

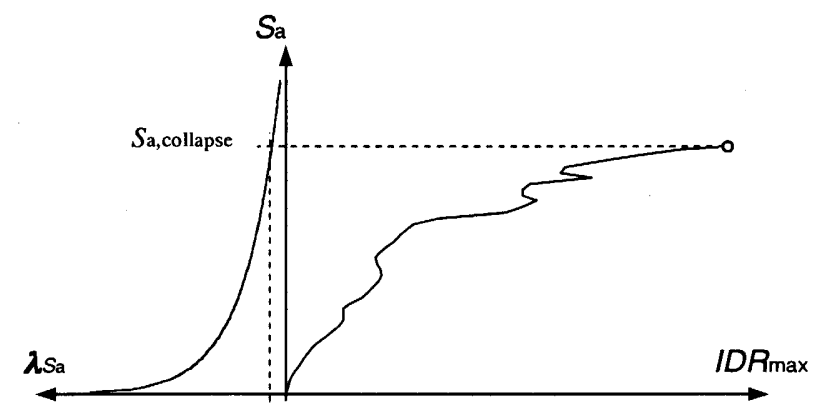

Fig.9 A hazard curve and a collapse capacity derived from an incremental dynamic analysis 
わらず IDRmax が減少する現象が数回確認できる。この“リターン現 象”は, 動的地震応答解析に用いられる入力地震動のスケールの違い により, 降伏のタイミングの変化や, 正側と負側の最大值の入れ替 わりなどが起こり, その結果, 生じるものである ${ }^{6}$ 。

最終的には部材の耐力低下, および $P-D$ 効果を伴い, 変形が発散 的に大きくなるので, それ以上の地震強さに対して解析を続けるこ とができなくなる。この発散直前の地震強さ $S_{\mathrm{a}}$ を崩壊キャパシティ

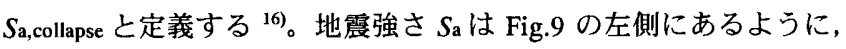
地震動の年間超過度数と対応しているから，その建物が崩壊キャパ シティに達する時の年間超過度数を求めることができる。

\section{4 漸増動的地震応答解析の統計処理}

上記の漸増動的地震応答解析を 40 個の地震動に対して行った結 果が, Fig.10である。縦軸に地震強さである $S \mathrm{a}$, 横軸に応答工学量 としてIDRmax をとつており, グレ一の曲線一本が, 一つの地震動に 対する漸増動的地震応答解析の結果を表している。

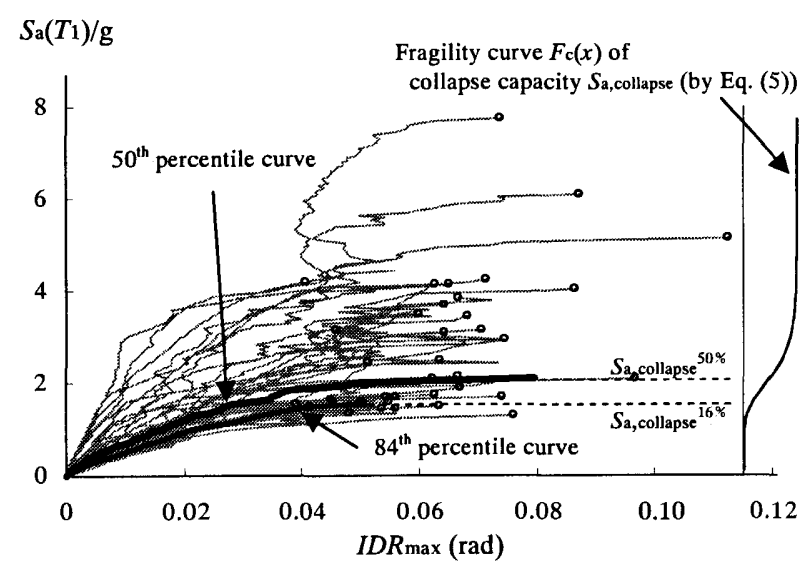

Fig.10 A set of results from incremental dynamic analyses on $\mathbf{4 0}$ ground motions (Case-2)

Fig.8に示されるように, 各地震動は, 一次固有周期に基づく弾性 応答值 $S_{\mathrm{a}}$ を基準としてスケールされるので，一次モードが卓越し， 応答が弾性範囲にとどまる条件では，応答のバラツキは小さく抑え られる。しかし，地震強さ $S \mathrm{a}$ が増加することに伴う非線形化により， 応答のバラツキは避けられない7。

このようなデータの統計処理であるが，「2.3」で述べたリターン 現象のため, 得られたデー夕を地震強さの軸に対して統計処理する ことと，応答工学量の軸に対して統計処理することは同義でない。 すなわち, 崩壊キャパシティ以前における解析結果を, あるIDR max の值に対して地震強さ軸方向にカウントしていくと, 一つの地震動 の解析結果をダブルカウントしてしまう場合が生じる。

本報告では，崩壞確率に関しては，地震強さ軸に対する統計処理 から崩壊キャパシティのフラジリティカーブを求めることで, また, 損傷過程に関しては，応答工学量軸に対する統計処理から破壊曲線 を求めることで，それぞれ，評価を試みる ${ }^{16) 。 ~}$

(1) 崩壊フラジリティカーブと崩壊確率

崩壊フラジリティカーブは, 40 個の地震動に対して得られた崩壊 キャパシティ $S_{\mathrm{a}, \text { collapse }}$ のデータを地震強さである $S_{\mathrm{a}}$ 軸方向に整理す ることにより得ることができ，式(2)により表すことができる ${ }^{16) 。}$

$$
F_{\mathrm{c}}(x)=P\left[S_{\mathrm{a}, \text { collapse }} \leq x\right]
$$

ここに, $F_{\mathrm{c}}(x)$ は, $S_{\mathrm{a}}$ が $x$ のときの崩壊フラジリィカーブの值であり,
崩壊キャパシティ $S_{\mathrm{a}, \text { collapse }}$ が $x$ 以下のときの確率となる。 崩壊フラジリティカーブが定義できれば，崩壞に対する確率的な 評価が可能となる。すなわち, 地震強さ $S_{\mathrm{a}}$ に対するハザードカーブ と崩壊フラジリティカーブ $F_{\mathrm{c}}(x)$ を式(3)において数值積分すること により, ”崩壊に対する年間超過度数入collapse”を求めることができる。

$$
\lambda \text { collapse }=\int_{0}^{\infty} F_{\mathrm{c}}(x)|\mathrm{d} \lambda \mathrm{sa}(x)|
$$

ここに, $\lambda S_{\mathrm{a}}(x)$ は $S_{\mathrm{a}}$ が $x$ を超える年間超過度数。

崩壊フラジリティカーブ $F_{\mathrm{c}}(x)$ は, 得られた崩壊キャパシティのデ 一夕に対数正規分布をフィッテングさせることにより求める。この 場合, 自然対数 $\ln \left(S_{\mathrm{a}, \text { collapse }}\right)$ の平均值および標準偏差を, 正規分布の 累積分布関数に代入する方法が一般的に考えられる。しかし，こう した非線形地震応答解析の結果においては, 少数の大きな值が全体 に及ぼす影響が強すぎるため, 代わりに自然対数のパーセンタイル 値を用いる方が, 分布形状を適切に表現できる ${ }^{17) 。 こ こ て ゙, ~} y$ パー センタイル值とは, フラジリティカーブ上で $y$ パーセント目の值 $x$ を指す（50パーセンタイル值は中央值に等しい）。

本研究では, 以上を踏まえ, $\ln \left(S_{\mathrm{a}, \text { collapse }}\right)$ の中央值 $\ln \left(S_{\mathrm{a}, \text { collapse }}\right)^{50 \%}$ および等価対数標準偏差 $\delta_{\mathrm{eq}}$ を用いた対数正規分布により, 解析結果 を表現する。等価対数標準偏差 deq に関しては, 16 パーセンタイル 值 $\ln \left(S_{\mathrm{a}, \text { collapse }}\right)^{16 \%}$ およ゙ 84 パーセンタイル值 $\ln \left(S_{\mathrm{a}, \text { collapse }}\right)^{84 \%}$ が, $\ln \left(S_{\mathrm{a}, \text { collapse }}\right)^{50 \%} \pm \delta$ eq に相当すると仮定することにより求めることが できる。(これは, 正規分布において, 平均值から標準偏差の距離に おける值が 16 パーセンタイル值と 84 パーセンタイル值に対応する ことから設定された仮定である。）一方, 崩壊フラジリティカーブ $F_{\mathrm{c}}(x)$ は, 式(3)において, ハザードカーブにおける年間超過度数 $\lambda s_{\mathrm{a}}(x)$ の微分, すなわち年間度数 $\mathrm{d} \lambda \mathrm{sa}(x)$ と組み合わされるので, 最終アウ トプットである崩懐の年間超過度数 $\lambda$ collapseに対しては, 大きな年間 度数 $\mathrm{d} \lambda \mathrm{s}(x)$ に対応する部分を, より的確にフィッテングさせるほう が合理的である。したがって，等価対数標準偏差 $\delta_{\mathrm{eq}}$ は，中央值より 小さなパーセンタイル值の部分に焦点を当てた式(4)より求める。

$$
\delta_{\text {eq }}=\ln \left(\frac{S_{\mathrm{a}, \text { collapse }}{ }^{50 \%}}{S_{\mathrm{a}, \text { collapse }}{ }^{16 \%}}\right)
$$

以上より,式(5) を用いて崩壊フラジリティカーブ $F_{\mathrm{c}}(x)$ を求める。

$$
F_{c}(x)=\Phi\left(\frac{\operatorname{Ln}(x)-\operatorname{Ln}\left(S_{\mathrm{a}, \text { collapse }}{ }^{50 \%}\right)}{\delta_{\mathrm{q}}}\right)
$$

\section{ここに， $\Phi(\cdot)$ は正規分布の累積分布関数。}

求められた崩壊フラジリティカーブ $F_{\mathrm{c}}(x)$ を Fig.10に付記している。 (2) 損傷過程

地震強さに対する応答工学量のパーセンタイル值を結び, 破壊曲 線に相当するパーセンタイル曲線として表す。ただし，応答工学量 軸に対する統計処理においては, 地震強さである $S_{\mathrm{a}}$ が比較的小さい 段階で崩壊キャパシティに達するものが出てくることにより，デー 夕のセットが不完全になる。すなわち, テータの数が $S \mathrm{a}$ の増大に伴 って 40 から減っていくことになる。したがって, 残ったデータセッ トのうち, 值が小さいものから順に並べて，20 番目と 21 番目の平 均值を中央值 $50^{\text {th }}$ パーセンタイル (counted $50^{\text {th }}$ percentile) とし, 34 
番目を $84^{\text {th }}$ パーセンタイル(counted $84^{\text {th }}$ percentile)とする ${ }^{16)}$ 。Fig.10 において, IDR $\max$ の中央值 $50^{\text {th }}$ パーセンタイル曲線は, 20 個目が崩 壊キャパシティに達した時点で消滅する。

ここで, 横軸最大層間変形角 $I D R$ max に対する $50^{\text {th }}$ パーセンタイル 曲線と $84^{\text {th }}$ パーセンタイル曲線の最後のポイントは, それぞれ, 縦 軸地震強さ $S_{\mathrm{a}}$ 方向に対する崩壊キャパシティの中央值 $S_{\mathrm{a}, \text { collapse }} 50 \%$, および 16 パーセンタイル値 $S_{\mathrm{a} \text {,collapse }}{ }^{16 \%}$ に相当する。

このようなパーセンタイル曲線を整理した資料は，ある地震ハザ ードレベルが与えられたときの性能評価において有用となる。例え ば, ある地震八ザードレベルに対応する $S_{\mathrm{a}}$ が与えられたときに, 最 大層間変形角 $I D R_{\max }$ の中央值 $50^{\text {th }}$ パーセンタイルを読み取ること は, ”ある地震ハザードレベルに対するIDR $\max$ の 50\%超過確率”を読 み取ることと同義である。

\section{3. 漸増動的地震応答解析の結果とその考察}

3.1 応答工学量に対する破壊曲線（EDP-direction statistics）

以下, 応答工学量のパーセンタイル值から得られる破壊曲線を比 較することにより，メカニズムコントロールが建物の損賃過程に及 ぼす影響を考察する。

\section{（1）履歴吸収エネルギーの総和と最大塑性回轱角の総和}

鉄筋コンクリート部材が受ける損傷の評価として，Park らは，最 大変形の終局変形に対する割合と, エネルギ一吸収による疲労度の 項からなる損傷指標 $D$ を提案している ${ }^{18)}$ 。高橋らは,これを利用し， 一質点系の解析より求まる建物としての損甥指標 $D$ と補修費用の関 係に, 線形や $\mathrm{S}$ 字などの複数のモデルを仮定して補修費用評価を行 う合理的な手法を提案している ${ }^{19}$ 。これに対応する応答工学量とし て,すべてのヒンジにおける最大塑性回転角の総和 $\theta$ max,sum および履 歴吸収エネルギーの総和 $E_{\text {sum }}$ を取り上げる。

まず, Fig.11(1)に, ヒンジにおける履歴吸収エネルギーの総和 $E_{\text {sum }}$ の中央值 $50^{\text {th }}$ パーセンタイル曲線を示すが，崩壊キャパシティ到達 以前において挙動が安定している範囲内では, メカニズム領域の大 きさに関わらず，ほぼ同一線上を通っており，建物の総エネルギー 吸収量はメカニズム領域の大小による影響を受けないことが確認で きる。Case-2 の最後の段階では，その勾配が小さくなり，Case-3お よび Case-4 と離れていく傾向にあるが, 多くの部材がすでに耐力低 下の負勾配に入っている。続いて, Fig.11(2)における最大塑性回転 角の総和 $\theta_{\text {max,sum }}$ の場合であるが，Esum の場合と同様の傾向にあり， メカニズム領域の大小による影響を受けないと言える。

一方, ヒンジの履歴吸収エネルギ一の平均值 $E_{\mathrm{ave}}$ および最大塑性

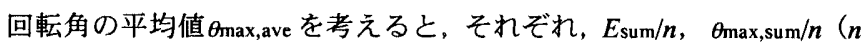
はヒンジの数) と表される。ここで, 上記のように $E_{\text {sum }}$ および $\theta_{\text {max,sum }}$ はメカニズム領域に影響を受けないので，メカニズム領域の大きさ が異なる場合の個々のヒンジにおけるエネルギー吸収レベルおよび 最大塑性回転角レベルは，ヒンジの数に反比例する形で異なること となる。これは, ヒンジの数が少ない Case-1 が, 他に比べ極端に小

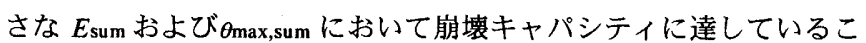
とからも明らかである。この場合，仮に，部材補修費用に対して最 大塑性回転角が支配的としても，すべての部材レベルにおける最大 塑性回転角と補修費用の関倸が同一の正比例関係で近似できる場合 においてのみ, 最大塑性回転角の総和と補修費用の総和が対応する
こととなる。

実際には，このような関係は極めて稀なケースで, メカニズム領 域が大きく異なる場合には, 部材の補修費用評価を個別に行って総 和する方向性を合わせて検討する必要がある。この点については今 後の課題としたい。

\section{（2）最大層間変形角}

建物の崩壊に対しては，層としての最大変形が密接に関係してい ると考えられる。Fig.11(3)には最大層間変形角 $I D R_{\max }$ の中央値 $50^{\text {th }}$ パーセンタイル曲線の比較を示す。この場合は, メカニズム領域の 大きさによる傾向の差が見て取れ, 同一の地震強さ $S_{\mathrm{a}}$ に対して，1 階が層崩壊する Case-1 のIDR $\max$ が最も大きく，メカニズム領域が

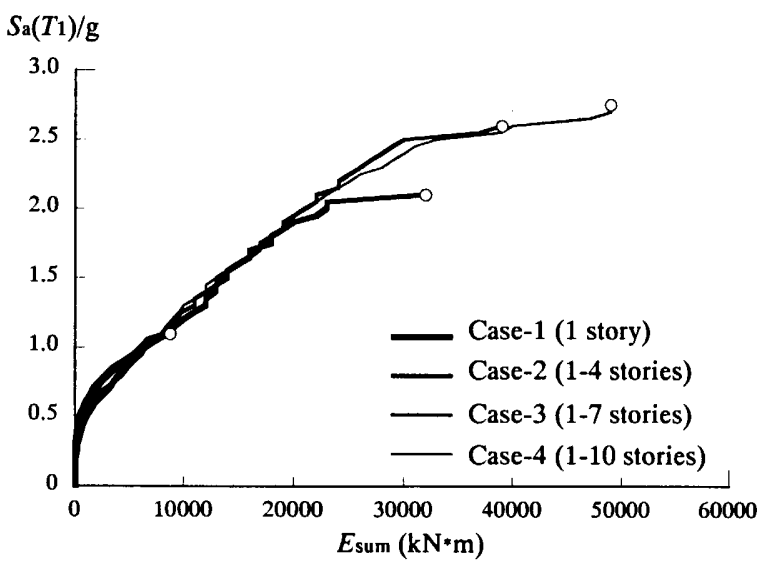

(1) Sum of hysteretic energy dissipation in all hinges

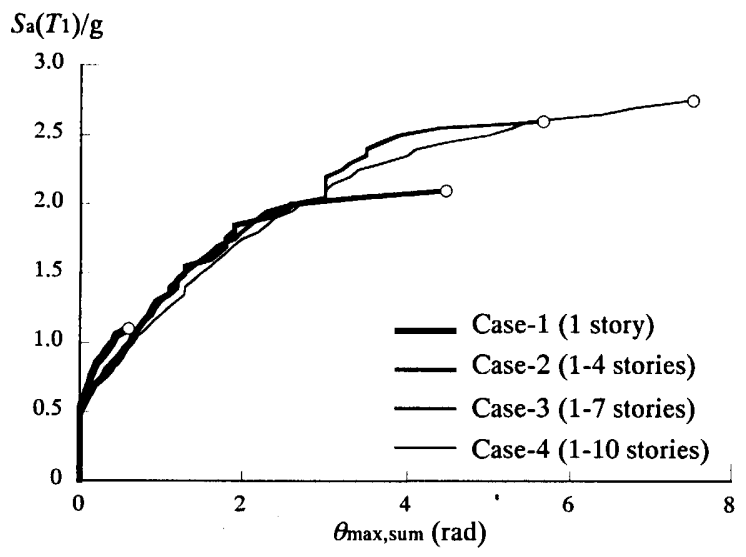

(2) Sum of maximum plastic rotations in all hinges

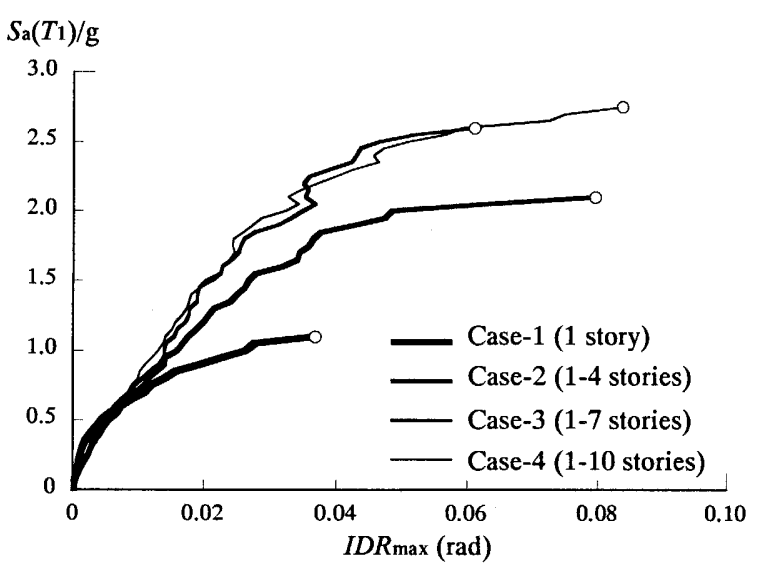

(3) Maximum inter-story drift ratio

Fig. 11 Median $50^{\text {th }}$ pecentile curves for EDP 
大きくなることにより，その值が小さくなっていく。

図中, Case-1 は, IDRmax が他のものより小さな時点で崩壊キャパ シティに達しているが，その理由は $E_{\text {sum }}$ および $\theta_{\text {max,sum }}$ の場合 （Fig.11(1)，Fig.11(2)）と本質的に異なる。すなわち，1 階のみがメ カニズムに達する Case-1 の場合には, ヒンジの履歴が負勾配に入っ た後の余力が小さく，ある点において急激に層間変形が発散してし まうため, その勾配が極めて小さくなる。したがって，地震強さ $S$ a の增分量をさらに細かくすれば, Case-1 の場合も，崩壊キャパシテ イ時の IDR max を大きくすることは出来るが，実質上，崩壊確率評価 の対象となる崩壊キャパシティ $S_{\mathrm{a}, \text { collapse }}$ の值には影響を及ぼさない。

一方で，同一地震強さに対するIDR max の差は，メカニズム領域が 大きくなるに従い，小さくなる傾向にある。この第一の理由として は, 最大塑性回転角の平均值 $\theta_{\max , \text { ave }}$ が, 前述のように, ヒンジの数 $n$ と反比例の関係にあることが挙げられる。1/n により, Case-1, Case-2, Case-3, Case-4 における $\theta_{\max , a v e}$ の比は, 1/14:1/50:1/86:1/122 と表され，この $\theta_{\text {max,ave }}$ と IDR $\max$ に一定の相関があると考えれば, その差が小さくなっていく現象が理解できる。

加えて, もう一つの重要な傾向を, Fig.12 に示す同一の地震強さ $S \mathrm{a}$ における各階の最大層間変形角 $I D R \mathrm{i}$ の中央值分布形状から読み 取ることができる。すなわち，図 Story 中, メカニズム領域が 1 階から 10 階までの Case-4 に注目すると,メ カニズム領域内の変形が下層階に おいて卓越し, 上層階の変形が小 さくなっている。したがって， Fig.11(3)のIDRmax において Case-4 と Case-3 が極めて近くなってい る傾向に関しては, ヒンジの数の 增加割合が小さい，という点に加 えて,メカニズム領域が大きい(高 さ方向に長い）場合には, メカニ ズム領域内の上層部分においてエ ネルギー吸収割合が小さい, とい う点が要因として挙げられる。

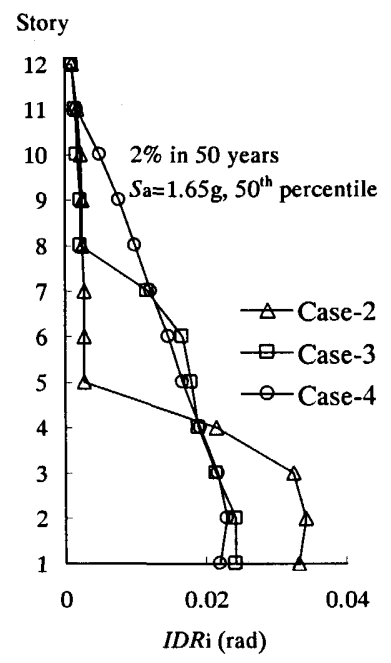

Fig.12 IDRi distributions

\section{2 崩㙘確率 (IM-direction statistics)}

崩壞キャパシティのフラジリティカーブ $F_{\mathrm{c}}(x)$ は 式(2)において表 現されるが, 具体的に式(5)を用いて各ケースのフラジリティカーブ $F_{\mathrm{c}}(x)$ を求めたのが Fig.13 である。図中, 1 階が層崩壊する Case-1 は, 地震強さ $S_{\mathrm{a}}$ が小さい段階において崩壊確率が大きくなるが, メカニ ズム領域が大きくなるに従って同一の $S \mathrm{a}$ に対する崩壊確率が小さ くなる。ただし, その差もメカニズム領域が大きくなるに従って小 さくなる。こうした傾向は, IDR $\max$ の傾向と一致する。

また，メカニズム領域が大きくなるに従い，形が $S_{\mathrm{a}}$ 軸方向に広が り，崩壊キャパシティ $S_{\mathrm{a} \text {,collapse }}$ の地震動に対するバラツキが大きく なることが示陵されている。これは, 層崩壊する Case-1 のヒンジが 一斉に負勾配に入るのに対し, メカニズム領域が大きくなるために ヒンジが負勾配に入るタイミングが各層で異なることとなり, さら に，その後における建物としての余力も增えるためである。

一方, 式(3)に用いる地震強さ $S_{\mathrm{a}}$ に対するハザードカーブは, 式(6)
により表現できると仮定する ${ }^{20) 。 ~}$

$$
\lambda_{S \mathrm{a}(T 1)}\left(S_{\mathrm{a}}\right)=k 0 \cdot S_{\mathrm{a}}{ }^{-k}
$$

Fig.7 に示す一様ハザードスペクトルにおいて， $T_{1}=0.813 \mathrm{sec}$ に対 する線形補間から得られる 50 年発生確率 $2 \%$ (年間超過度数 1/2475) の $S_{\mathrm{a}}=1.65 \mathrm{~g}$, および 50 年発生確率 $10 \%$ （年間超過度数 $1 / 475 ） の$ $S_{\mathrm{a}}=0.97 \mathrm{~g}$ を用いて, 式中の形状係数 $k 0$ および $k$ を求めれば Fig.14 に 示すハザードカーブが得られる。

Fig.13および Fig.14 は，いずれも Sak対する崩壊キャパシティの フラジリティカーブと年間超過度数のハザードカーブであり, 式(3) により, 数值解析を用いて, 崩壊の年間超過度数 $\lambda$ collapse を求めるこ とができる。求められた崩壊の年間超過度数入collapse は, 式(7)のポア ソン過程から $t$ 年間中における崩壊確率 $P($ collapse $\mid t)$ へ展開すること ができる。年間超過度数 $\lambda$ collapse の值が非常に小さい場合には, 年間 崩壊確率 $(t=1)$ は年間超過度数 $\lambda$ collapse とほぼ等しくなる。

$$
P(\text { collapse } \mid t)=1-\exp (-\lambda \text { collapse } \cdot t)
$$

以上より, 年間崩壊確率および建物の供用期間として $t=50$ 年を仮 定した場合の崩壊確率を Fig.15 に示す。図中，1 階が層崩壊する Case-1 は，年間崩壊確率，供用期間 50 年崩壊確率とも突出してい て，崩壊に対する危険度が高い。一方，メカニズム領域を 4 階まで 広げて梁ヒンジの数を增やすことにより（Case-2), 危険度が急激に 緩和されることがわかる。メカニズム領域を 7 階, または 10 階まで 広げることにより（Case-3，Case-4)，さらに危険度を緩和すること ができるが，両者は極めて近い值となり，こうした傾向は同一の $S_{\mathrm{a}}$ に対する崩壊フラジリティカーブの傾向（Fig.13）と一致する。

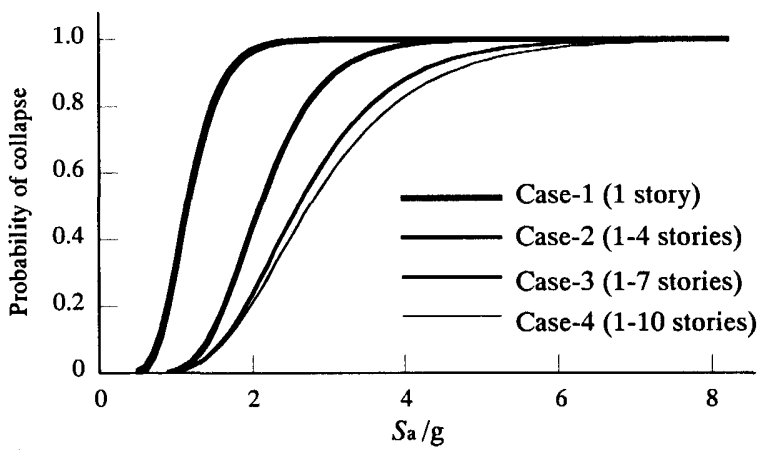

Fig.13 Fragility curves of collapse capacities for $\mathrm{Sa}$ axis

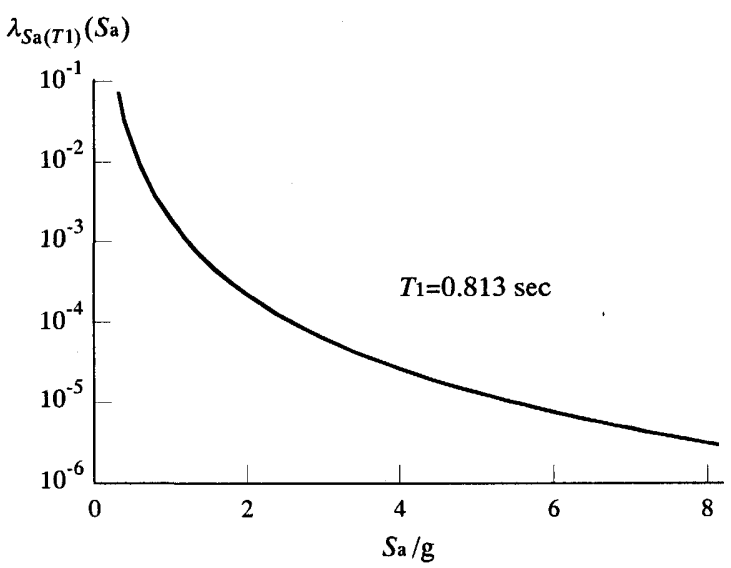

Fig.14 The hazard curve for $S a$ at Van Nuys 
$(\%)$

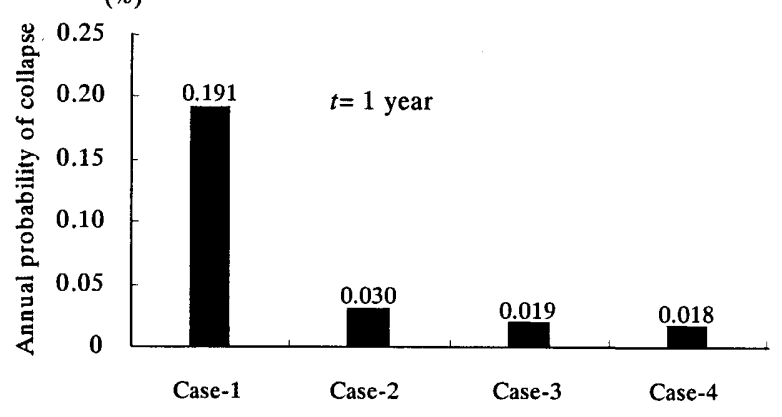

(\%)

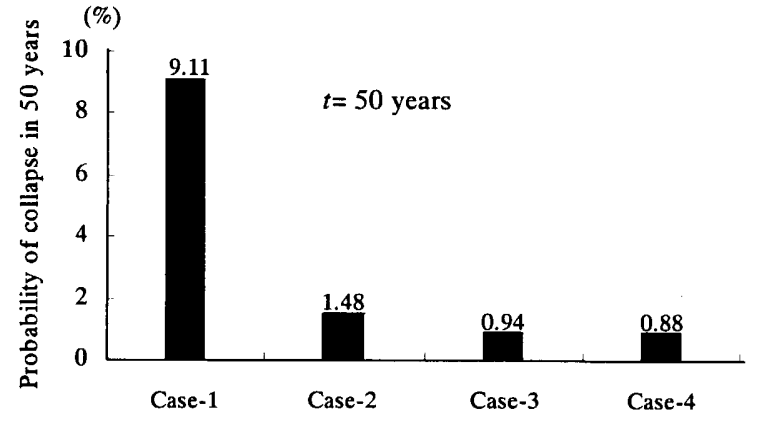

Fig.15 Annual probabilities of collapse and probabilities of collapse in $\mathbf{5 0}$ years

\section{4. 結論}

本報告では，地震後に無損傷領域を確保するメカニズムコントロ 一ルという概念を提案し，メカニズム領域の大きさが建物の耐震性 能に及ぼす影響を確率論的アプローチから考察した。対象とした建 物は, 全体朋壊形に対する終局強度設計が行われた 12 階建て鉄筋コ ンクリートフレーム構造で, 上層部を弾性とすることで無損賃領域 を仮定し，そのメカニズム領域を 1 階のみの場合から 3 首ずつ增大 させた。想定するサイトの地震ハザードとしては, 米国カリフォル ニア州 Van Nuysに対する解析結果を用いた。

以上の条件下で得られた知見を以下にまとめる。

(1) 応答工学量軸に対する統計処理（応答工学量破壊曲線）より

各部材の履歴消費による総エネルギー吸収量, および各部材の経 験した最大塑性回転角の総和は, メカニズム領域の大きさに影響さ れない。

それに対して, 同一の地震強さに対する最大層間変形角は, メカ ニズム領域が大きくなるに従って小さくなる。

ただし, 最大層間変形角を減少させる効果は, メカニズム領域が 大きくなるに従って小さくなる。この傾向は, 最大塑性回転角の平 均がヒンジの数に反比例する形となることから説明できる。さらに, メカ二ズム領域が 1 階から 10 階までになると, 変形が下層階におい て卓越することとなり，その効果は一首小さくなる。

(2) 地震強さ軸に対する統計処理（崩壊確率）より

崩壊に対する定量的な性能表現は，メカニズム領域を決定する際 の明確な資料となり得る。

本研究において，地震強さに対するハザードカーブと崩壊キャパ シティのフラジリティカーブから算出された年間崩壊確率は, メカ ニズム領域が 1 階のみの場合, 1 階から 4 階までの場合, 1 階から 7 階までの場合, および 1 階から 10 階までの場合に対して,それぞれ，

$0.191 \%, 0.030 \%, 0.019 \%, 0.018 \%$ となった。
傾向としては，(1)の最大層間変形角に等しく, メカニズム領域が 1 階のみの場合においては崩罟危険度が突出するが，メカニズム領 域を 4 階まで広げることにより，危険度が大きく緩和できる。メカ ニズム領域を 7 階または 10 階まで広げることにより,さらに危険度 を緩和することができるが，両者は極めて近い值となる。

\section{謝辞}

本研究においては,スタンフォード大学地震工学センターPaul Cordova 氏, Jorge Ruiz-Garcia 氏，Hasameddin Aslani 氏，Jack Backer 氏，Farzin Zareian 氏 から御意見頂きました。ここに記して謝意を表します。

\section{参考文献}

1) 鉄筋コンクリート造建物の終局強度型設計指針・同解説, 日本建築学会, 1990

2) T. Paulay: A Critique of the Special Provisions for Seismic Design of the Building Code Requirements for Reinforced Concrete (ACI 318-83), TECHNICAL PAPER, ACI Journal, pp.274-283, March-April, 1986

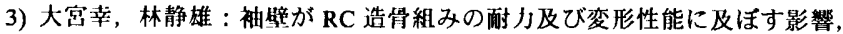
コンクリート工学年次論文集，Vol. 24，No.2，pp.469-474， 2002

4) http://peer.berkeley.edu/

5) C. Allin Cornell and Helmut Krawinkler : Progress and Challenges in Seismic Performance Assessment, PEER Newsletter Vol.3, No.2, Spring 2000

6) Vamvatsikos, D. and Cornell, C.A. : Incremental Dynamic Analysis, Earthquake Engineering and Structural Dynamics, 31, 3, 491-514, 2002

7) 長江拓也, Helmut Krawinkler：地霞時における鉄筋コンクリート建物の破

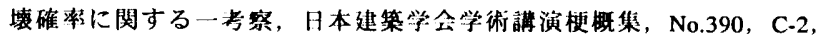
pp.745-746, 2004

8) T. Lee, K. M. Mosalam : Sensitivity of seismic demand of a reinforced concrete shear-wall building, Applications of Statistics and Probability in Civil Engineering (the ICASP-9 Conference), pp. 1511-1518, 2003

9) T. Takeda, M. A. Sozen, N. N. Nielsen : Reinforced Concrete Response to Simulated Earthquakes, Journal of the Structure Division, ASCE, ST12, pp. 2557-2573, 1970

10）菅野俊介：鉄筋コンクリート部材の復元力特性に関する研究，コンクリ ートジャーナル, Vol.11, No.2, 1973

11) FEDERAL EMERGENCY MANAGEMENT AGENCY:PRESTANDARD AND CMMENTARY FOR THE SEISMIC REHABILITATION OF BUILDINGS (FEMA356/November2000)

12) Medina : Seismic Demands for Nondeteriorating Frame Structures and Their Dependence on Ground Motions, Ph. D. thesis, Stanford University, 2003

13) EERI Committee on Seismic Risk: The Basics Risk Analysis, Earthquake Spectra, 5 (4), 675-702, 1989

14) Shome N., Cornell C.A. : Earthquakes, Records, and Nonlinear Responses, Earthquake Spectra, 14 (3), 469-500, 1998

15) Somerville P, Cornell C.A. : Ground Motion Time Histories for the Van Nuys Building, PEER Methodology Testbeds Project, URS Corporation, Pasadena, $\mathrm{CA}, 2002$

16) Luis F. Ibarra and Helmut Krawinkler : Global Collapse of Deteriorating MDOF Systems, 13 ${ }^{\text {th }}$ WCEE, Paper No. 116, 2004

17) Eduardo Miranda, Hesameddin Aslani : Probabilistic Response Assessment for Building-Specific Loss Estimation, PEER Report 2004/03, September, 2003

18) Park Y. J., Ang A. HS. : Mechanistic Seismic Damage Model for Reinforced Concrete, ASCE Journal of Structural Engineering, 111-4, 722-739, 1985

19）高橋典之, 㙁原等, 小谷俊介, 東川敬子 : 鉄筋コンクリート建物構成要 素のライフサイクル修復経費に及ぼす影響, コンクリート工学作次論文集, Vol. 24, No.2, pp.43-48, 2002

20) Cornell C.A., Jalayer F., Hamberger R., Foutch D. : Probabilistic Basis for 2000 SAC Federal Emergency Management Agency Steel Moment Frame Guidelines, ASCE Journal of Structural Engineering, 128(4), 526-534, 2002

(2004年 12 月 10 日原稿受理， 2005 年 3 月 23 日採用決定) 